\title{
Permanent Temporariness? Changes in Social Contracts in Knowledge Work
}

\section{Bente Rasmussen}

Department of Sociology and Political Science, Norwegian University of Science and Technology (NTNU), Trondheim, Norway ${ }^{1}$

\section{Tove Håpnes}

SINTEF Technology and Society, Trondheim, Norway

\begin{abstract}
Many sociologists have argued that work no longer plays the central role in contemporary life experience because we have entered an age of insecurity in relation to employment, and knowledge workers are often pictured as egoistical portfolio workers who are only interested in their careers and no longer loyal to their employers. Cappelli (1999) on the other hand argues that more insecure employment relations is a result of employers' strategy to buy workers rather than offering them long-term relations.

Using case studies from seven different knowledge work contexts in Norway, this article argues that more temporary employment relations is not the result of career-seeking portfolio workers, but of changes in employment practices of their employers. These are not primarily changes in the formal employment contracts from permanent to temporary employment, but in the social contracts as they are practiced by the employers and experienced by the knowledge workers in the different contexts of knowledge work. The reason for more temporary relations was not because work does not matter for knowledge workers. On the contrary, we found that they accepted insecure conditions because work mattered and because they were eager to take on new tasks, learn the trade in new fields, and show that they were able to do the job. When they left their employer, it was because they were not able to do a good job in their positions or because they were increasingly directly exposed to an insecure market that signaled that they were not profitable (enough) for their employer. Although changes in employment practices by the employers toward more short-term relations are not caused by disloyal portfolio workers, these practices may produce the problem of disloyal workers who have to secure their employment in the labor market.
\end{abstract}

\section{KEYWORDS}

Employment practices / knowledge workers / meaning of work / social contracts.

\section{Introduction}

any sociologists have argued that work no longer plays the central role in contemporary life experience because we have entered an age of insecurity in relation to employment (Beck 2000; Sennett 2004). This insecurity in employment is claimed to have consequences for the social and personal lives of workers leading to

\footnotetext{
${ }^{1}$ Bente Rasmussen, Institutt for sosiologi og statsvitenskap, NTNU, N-7491 Trondheim, E-mail: bente.rasmussen@svt.ntnu.no
} 
individualization, undermining the work ethic and work as the central basis for people's identities (Beck 2002). While most attention has been paid to flexibilization and the erosion of permanent employment relations for workers in manual trades and services (Castells 1996; Elliot \& Atkinson 1998; Standing 2009), we also find more insecurity about employment among knowledge workers (Baldry et al. 2007; Brown \& Hesketh 2004; Felstead et al. 1998). For knowledge workers, however, work is still understood as central for their identity because they have invested time and effort in many years of education (Alvesson 2000). Although work is seen to matter for knowledge workers, in the literature on knowledge work they are often pictured as individual economic agents seeking to profit from their investment in qualifications. The image of portfolio workers who are only interested in their careers and no longer loyal to their employers illustrates this (e.g., Handy 1989).

In a similar vein, Drucker (1993) has argued that knowledge has become the new 'capital' taking over from the factories and machines of industrial society, and that this fundamentally changes the power relation between knowledge workers and their employers in favor of the workers (see also Donnelly 2009, p. 324). The argument is that when the capital, knowledge, is the property of the workers, located 'in their heads,' they may walk away with their knowledge to another employer who offers them a better deal. Following Drucker's argument, employers are therefore in danger of becoming the victims of knowledge workers (or capital bearers) who are no longer loyal to their employer, but follow their personal interests and careers.

Cappelli (1999) argues that more flexible employment relations are the result of employers answering to the demands of profitability in a competitive market for knowledge-intensive products and services. Changes in markets, technology, and the drive for innovation put pressure on organizations to access cutting-edge knowledge. To do this, companies increasingly 'buy' this knowledge within the labor market rather than develop the necessary knowledge in the organization by investing in their employees in a long-term perspective. The result is a 'new deal at work,' where the companies offer challenging tasks and professional development, but no long-term employment. It is then up to the knowledge worker's efforts to survive in the company and sustain their own career (Cappelli 1999). The main benefit from employment of the new deal is an attractive CV and the advantage that this brings in the job market (Kunda \& AilonSouday 2004).

Increased turnover and mobility in knowledge work organizations are used as evidence for both types of argument. Whether an individualized career orientation is a consequence of insecure employment relations or an argument for short-term relations for the firms, the discourses about knowledge workers as disloyal portfolio workers posit the knowledge workers as individual economic actors in a labor market where their individual interests in increasing their market value is the central driving force. Since the current debate on knowledge work is dominated by business and management scholars (Darr \& Warhurst 2008), this is not unexpected. Work as an intrinsic value and the workplace as a collective arena of production, central to the identity of the knowledge workers, is not the focus in this understanding of knowledge workers.

Doherty (2009) challenges the view of the end of work as identity. In a study of workers in four large organizations in Britain, he found that work fulfilled important personal and social needs for all types of workers, and that the workplace remained an important arena for social relations. Following his argument, this article argues that 
the weakening of ties between knowledge workers and their employers manifest in increased turnover is not the result of career-seeking portfolio workers, but of changes in the employment practices of their employers. These are not primarily changes in the formal employment contracts from permanent to temporary employment, but in the social contracts as they are practiced by the employers and experienced by the knowledge workers in the different contexts of knowledge work. In this article, we will show that the reason for more temporary relations is not because work does not matter for knowledge workers. On the contrary, we found that they accepted insecure conditions because work mattered and because they were eager to take on new tasks, learn the trade in new fields, and show that they were able to do the job. When they left their employer, it was because they were not able to do a good job in their positions or because they were increasingly directly exposed to an insecure market that signaled that they were not profitable (enough) for their employer.

\section{Employment relations in knowledge work}

The discourses about employment relations in knowledge work that we have described have very different conceptions of power relations between knowledge workers and their employers. In Drucker's (1993) description, the knowledge workers have become the most powerful part in these relations since they control the most important means of production, the 'knowledge capital'. This is also the case in the discourses of careerseeking portfolio workers (Handy 1989). Cappelli (1999) describes a more contingent situation where a new deal will leave knowledge workers with less secure employment and with individual responsibility for their employability, their power in relation to their employer being dependent upon their situation in the labor market.

Cappelli's (1999) description of a new deal is mainly based on the development of employment relations in the US and therefore is not directly transferable to other national contexts. Although the regulation of labor contracts in Europe has been accommodated to more flexible forms of employment (Beck 2000), there are important national differences. In contrast to most other countries, the demand from employers in the 1990s for greater flexibility in employment contracts was not met by Norwegian authorities, and in 1995 the use of short-term or temporary employment contracts was restricted by law. The norm in Norway is therefore one of permanent contracts for all employees (see Olsen \& Kalleberg 2004)1. We would therefore not expect the same development toward flexible employment relations in Norway as in the US. Whether deregulation to accommodate more flexible employment relations has actually led to more short-term employment has also been contested, and the EU's employment statistics show that the rate of long-term employment increased rather than decreased through the 1990s (Doogan 2005). This indicates that employers are interested in longterm employment relations and that employment relations are dependent not only upon institutional contexts but also upon the economy and the labor market situation. In Norway, there is a very high participation in the labor market; $77 \%$ of the women and $85 \%$ of the men work (Kitterød \& Rønsen 2010). In a situation of growth in the economy, this has resulted in a scarcity of many types of professionals like university graduates in engineering, computer science, and economics - the type of workers who are covered by our research. We might expect that these employees would use the labor 
market to negotiate better jobs and conditions at work and certainly not expect that employers will introduce more short-term and less permanent employment relations with scarce groups of highly qualified knowledge workers, but rather that they will invest in them and try to keep them in the organization.

\section{Social contracts at work}

Changes in employment relations, as to the terms and duration of the relationship, are not limited to changes in formal employment contracts, but may also be found in the practices and the expectations of employers and workers concerning the time perspective of their relationship. These may again be a result of the discourses of portfolio workers and of practices of increased mobility among knowledge workers, creating an expectation that they should move to a new employer within a certain period. It may also be a result of a wider scope of insecurity at the societal level as a result of mergers and acquisitions and financial crises that have created an understanding of insecurity or a manufactured insecurity (Doogan 2001).

Such changes in employers' and workers' expectations about the time perspective and terms of their relationship change the psychological or social contract at work (Rousseau 1995; Schein 1985). The social contract, or the unwritten agreement regarding the relationship between workers and the organization, is shaped by the promises and practices of the organization. Social contracts are important in organizational life because people's commitment to an agreement make their actions predictable (Rousseau 1995). According to the principle of reciprocity (Gouldner 1960), there should be a balance between the demands that the organization places on the workers and the rewards that they may in turn expect from the organization. When the different parties agree on the terms and follow them, the social contract is reinforced. It may be broken, however, when the principle of reciprocity is violated because the balance is disturbed (Rousseau 1995).

The balance between efforts and rewards will vary depending upon whether the employment relation is a long-term or a short-term market transaction. When workers are being asked for extra effort and to suppress their personal needs for the good of the company, this makes sense in a long-term relationship where rewards may follow later. Delayed gratification, however, presupposes a long-term relationship where loyalty and effort are rewarded. In a short-term relationship, it is not possible to work for delayed gratification and it makes no sense to be loyal to an employer who only offers temporary employment (Sennett 1998).

In order to understand specific workplace relations, we need to study the local institutional and market situations that shape the work situations of knowledge workers (Barley \& Kunda 2001; Darr \& Warhurst 2008). Private firms employing knowledge workers are dependent upon the market for their products and services, and their market situation influences the employment relations and opportunities of workers (Courpasson 2000; Robertson \& Swan 2004; Scarborough 1999). In delivering products and services to customers, knowledge workers' relations with their employer are mediated through the markets and the relation with the customers.

Knowledge work is neither a well-defined nor a uniform category (Warhurst \& Thompson 2006). We follow Scarborough's (1999) defining characteristic of knowledge 
workers as workers who engage in knowledge work rather than an occupational definition. We define knowledge workers as employees who use their specialized knowledge and qualifications acquired through education and experience and make use of nonstandard solutions to their tasks (Alvesson 2004). Furthermore, in our cases, they solve problems and develop solutions for customers in the employment of an organization, selling their services in the market (Scarborough 1999). Knowledge workers are employed because of their expert knowledge and consequently expect autonomy and self-determination at work (Alvesson 2000, 2004; Barron et al. 2001). This is reinforced by adhocratic (Mintzberg 1979) or 'postbureaucratic' forms of organization, where the responsibility for results is devolved to teams of workers (Newell et al. 2002). In return, autonomous workers who have their work as a central interest in life are willing to work long hours (Deetz 1995). According to Alvesson (2000), high intrinsic work motivation is not the only reason why many knowledge workers work long hours. He argues that their work effort can also be understood within the perspective of their identity as knowledge workers. Alvesson therefore characterizes knowledge-intensive workers as the ideal subordinates and the employer's dream in terms of work motivation and compliance because so many work hard without supervision from the management (Alvesson 2000, p. 1104). A more critical interpretation of long hours culture among knowledge workers is that working long hours is necessary to meet performance targets and deadlines for delivering projects and required if they want to have a career in the organization (Baldry et al. 2007; Epstein et al. 1999; Halrynjo 2007; Voss-Dahm 2005).

Even if they are motivated by their work and willing to work hard and long hours to deliver good quality projects and meet deadlines, the loyalty and commitment of knowledge workers are dependent upon the organization honoring their side of the bargain, offering them interesting tasks and opportunities for professional development. Knowledge workers' efforts are decided by what they consider fair and reasonable to be expected from them as knowledge workers, and if it is no longer a balanced deal (Gouldner 1960; Rousseau 1995), they may leave if they have other options, an action that their employer in turn may understand as the action of a portfolio worker.

In this article, we are interested in the time perspective of employment relations and the balance between what knowledge workers are offered and their obligations, as well as their opportunities to influence their work and working conditions. Whether the balance between efforts and rewards is seen as fair or not may explain why they stay or leave the organization. Our main question is whether increased mobility in our cases is a result of egoistic career-seeking portfolio workers or of new employment policies and strategies in the organizations that employ them, conditions that do not allow them the opportunity to do a good job.

\section{Data}

Qualitative studies allow us an understanding of how work processes and workplace relations have an impact upon the opportunities and well-being of workers and their satisfaction with their employment, i.e., whether they want to stay or to leave the organization. To answer the question of if and why knowledge workers leave their employers, we use data from seven knowledge work contexts that were collected in two consecutive qualitative studies of the organization of knowledge work. The first project 
("Boundless work and greedy organisations")2 studied workers in the 'new economy' with long hour cultures and high turnover, who were the type of workers sustaining the idea of portfolio workers. We collected data from financial workers in a regional finance institution, from web designers and programmers employed in different (and continually changing) advertising agencies and from systems developers of web-based IT systems in a new collectively owned IT firm.

In the financial institution and the IT firm, we observed the employees in their daily work, participated in internal meetings and seminars, and took part in coffee breaks and social gatherings. We conducted in-depth interviews (of approximately 90 minutes) with strategic samples of workers differentiated by position, qualification, gender, and experience. We also interviewed managers and key informants and consulted written material and previous studies of the organizations. The web designers worked in different organizations when we interviewed them. They had, however, worked for shorter periods in the same organizations and were recruited using the 'snow-ball' method of sampling. Some of them we interviewed in their workplace, but since this was not always possible and because some of them were on their way out of the company, they were interviewed in cafés or hotel rooms.

Since two of the contexts, web design and the IT firm, were newly established businesses without any perspective of long-term relations with their employees, we became interested in how knowledge work organizations that depend upon long-term and stable employment relations managed to be competitive in a dynamic and changing market. In the next project ("From permanent relations to casual flings?") ${ }^{3}$, we therefore chose in-depth studies of departments of well-established large organizations that developed flexible organization structures (postbureaucratic forms of organization) to meet the demands from a turbulent market (Kanter 1989). In this project, we studied workers in research and development within two departments of a large international private research institution and a research laboratory of a large international industrial company. We also studied a public relations agency that delivered knowledge-based services on a commercial basis. We used the same design as in the first project with observation and participation in seminars, meetings, and social gatherings and long interviews with strategic samples of workers as well as managers and key informants in each research site. In two of the research departments, we also used focus groups. We made field notes during our observations and all interviews and focus group discussions were digitally recorded and transcribed verbatim. In each case, we interviewed about 10-11 employees and 1 or 2 operational managers.

We presented our findings in the organization where this was possible in both projects. In five of the organizations, masters students participated in the data collection and wrote a thesis based on their cases.

Our definition of knowledge workers as workers who do knowledge work (Scarborough 1999), irrespective of their level of formal education, resulted in a very varied group of workers. In our case, it includes self-taught web designers and software workers as well as scientists with a doctorate degree. The knowledge workers in our sample therefore worked in different types of firms in different market contexts and varied considerably according to turnover and mobility. Recognizing these variations, we are not aiming at giving an overall picture of employment relations in knowledge work in Norway. Instead, we want to understand the practices and processes shaping the duration of employment relations in our cases. 
We analyzed the data across both projects by reading carefully through all notes and transcriptions of each case, analyzing the cases individually and subsequently comparing the cases across projects. The comparisons across cases thematically examined working conditions (Håpnes \& Rasmussen 2008), power relations (Rasmussen 2008), and employment relations (this article). The two studies give insight into employment relations in different types of knowledge organizations from the 'new economy' to traditional knowledge-producing organizations. We found across the case studies a general development toward more insecure and less permanent employment relations. In our analysis, we distinguish between four different types of employment relations from very short-term to life-long relations. The four types are based on what we found to be relevant distinctions between the practices and interpretations of employment relations in the seven cases. The first three are different variations of more transactional types of social contracts (Rousseau 1995) or new deals (Cappelli 1999), whereas the fourth is a relational contract (Rousseau 1995) or the old deal (Cappelli 1999). The four types, as such, are part of our findings, and we use them to highlight key distinctions in the different employment relations in our cases.

We have grouped the cases according to characteristics relevant to the analysis of the employment relations, and they will be presented in the following order:

1) Short-term relations in the dot.com sector: web designers in advertising and a new IT company

2) 'On trial' in the 'new economy': financial services and public relations

3) Dependent upon economic results in research: construction and IT departments of an international research institution

4) Life-long relations in the research laboratory of a large international industrial company

\section{Dot.com: opportunity knocks}

The employment relations that we found in the dot.com sector were very intense, but of short duration, often ending in breakup where the employees felt deceived and let down by their employer. The relationship started, however, with enthusiasm and strong positive emotions on the side of the employees; a lot like falling in love. The dot.com companies were relatively new organizations offering young people opportunities to try their hand working with web design and web-based IT systems. For many, this was an opening into an attractive field where they could participate in the development of new products and technology.

Advertising is traditionally structured according to a strict hierarchy (Alvesson 1998) and the opportunity for employment as a graphic designer is dependent upon having the 'right' education. In Norway, this is the private Westerdals school of advertising to which it is very hard to gain entrance. Since there was no formal education in web design when we interviewed, trying their hand as a web designer was a backdoor into advertising, offering young people the opportunity to gain experience and build a portfolio to develop a career as designer. Programming web sites was also a new area, and all the programmers were self-taught. Since their motivation was high, it was not a problem that there was a culture in the organizations that demanded hard work and long hours 
to deliver on time. This meant unpaid overtime since the consultants who sold products on the web for the advertising agencies did not know the work process and how long it took to design the products, and did not ask the web designers.

The willingness of the young men and women to work unpaid hours waned, however, when the long hours became the rule rather than the exception:

'It's like giving someone a ball of wool and saying: "knit a sweater of this. It is to be size XL, and if it is not enough wool, that's your problem".' (web designer)

The agencies were eager to sell their customers new products on the web. This was a new and lucrative market. When the workers had to invoice 7 hours work a day at $£ 85$ there was much to be earned, especially when newly appointed workers were paid around $£ 15,500$ a year at that time. After being seduced by the opportunities that the advertising agencies offered, the web designers and programmers felt deceived when they experienced that their suggestions as to improving the working processes were not followed up, and that they were not treated as professionals, but as labor power to make huge profits on web pages for the customers of the agencies. The ultimate betrayal was when management argued that it was not necessary to make good designs since their customers wouldn't know the difference anyway. Then the deal was off for the ambitious young designers, and sacrificing family, friends, and private life working around the clock was no longer accepted. Thus the designers left the agencies to try somewhere else in the hope that they would be treated better there.

The IT firm also offered the opportunity to work with a new technology, and selftaught and newly educated computer scientists were offered jobs developing web-based systems for small firms. They were eager and enthusiastic to work in the frontline of the technology and very happy with this opportunity. In return, they were willing to give the organization everything to be able "to work with my hobby and even get paid for it," as one of the systems developers in the IT firm said, or

'The job in itself is so entertaining that there is no point in going home to watch TV. That's boring compared to this. It is turned upside-down. You relax more at work than at home in front of the TV.' (web programmer)

Working in organizations with other young people where the line between work and social life was blurred was like a continuation of their life as a student, only paid. The new IT firm invariably sold their products very cheaply to gain foothold in the market. It experienced turnover when the systems developers no longer accepted the pressure of long hours because their employer sold the projects too cheaply. Often the firm was not able to pay their wages on time because the customers had not settled their accounts. The firm argued that they would all get paid for their efforts when they were able to go public and realize the value in the company. The practice of playing at business, however, was not compatible with the professional identity of the system developers and, at a more practical level, was not compatible with having a family. The employees therefore demanded changes and ultimately quit, despite their interesting tasks and possible future prospects, because their employer was not able to fulfill their part of the deal. 
The employees in the dot.com firms therefore experienced short, but very intensive employment relations that started out with enthusiasm, but ended with disappointment and a feeling of being deceived when they experienced that the relation was one-sided and their employers were not willing, or not able, to meet their obligations. The employees demanded that the companies listened to them and organized their work so that they were able to deliver good quality products and meet the deadlines. As an experienced, self-taught systems developer in the IT firm voiced it:

'(W)e could certainly have managed to play postmodern organization with a flat structure for a long time, but to get a serious business off the ground, I think that you have to get organized.'

When the employers were not willing or able to meet their obligations, the employees were frustrated and disillusioned and left. The companies hired inexperienced and eager workers, and seduced new recruits when they left. As long as there was a supply of ambitious work-hungry young people, willing to accept the hard work and long hours for an opportunity to try their hand in the field, they could persist with this strategy. This resulted in short-term employment relations that made the firms vulnerable when their experienced workers left (Rasmussen \& Johansen 2002, 2005).

\section{Hired 'on trial'}

The jobs in the financial institution and the public relations agency were very attractive for young university graduates. Both were eager to hire the best people and presented themselves in the most favorable way for students at leading universities, and they had so far been successful. Recruiting was done using elaborate procedures where the candidates were interviewed and tested through 'real-life' cases to see whether they were suited for the job and had the right attitudes. Those that were chosen, however, did not earn a permanent position, but were given 'the opportunity to try their hand at the job,' with the prospect of a career in the firm. To be chosen therefore did not mean a long-term relation. They were hired 'on condition'; after their hiring there followed a 'trial' period. This was not, however, the regular trial period of 6 months in all employment relations in Norway in which the employer may terminate the relationship if there are sound reasons for this, specified in the law, but an implicit agreement that they would first have to prove themselves, often in competition with other candidates, to gain permanent employment in the organization. Since these were potentially attractive positions, the ones who were chosen were grateful for this opportunity.

In the public relations agency the positions were called trainees, but to work as a trainee did not mean that they learned the business of the organization by a gradual period of apprenticeship. The policy of the company was to throw them directly into the projects and expect them to produce, "because that was the best way to learn." Since they were on trial, they knew that they had to work hard to show that they were good enough to qualify for a permanent position. Success in the organization was not only a question of professional qualifications, but also of having the right 'drive,' being able to shoulder the work, fit in, and market themselves as professionally and 
economically attractive. It was explicitly stated that if they did not earn enough or produce as expected, they would have to find something else. As a result, the recruits would work as hard as they could and forsake family and friends. Being recruits and inexperienced, they did not know what was good enough and were therefore often not able to limit their efforts. Being noticed by leading seniors secured them attractive projects, but it also meant that they ended up participating in too many projects with a too heavy workload. The first years were called boot camp, a good illustration of the reality for the workers in this period. To show their worth, they worked hard to present themselves as able to deliver good quality solutions under pressure. It was therefore in the order of the day to end up 'burnt out.' When this happened they would hear stories from the older and established colleagues about when they burnt out, confirming that this was considered a normal thing for trainees. A project administrator told us about a colleague who had experienced burn out when they were both trainees:

'When she was off sick, several colleagues came and told me about when they had ended up burnt out. I thought, must everyone burn out here?'

In spite of an emphasis on teamwork and developing the competence of the workers, in the end what counted was the individual economic result as billed and paid hours that were demanded by their investors (Håpnes \& Rasmussen 2011a).

In the financial institution, economic results were also what counted. They recruited university graduates because they wanted to give better professional advice to their clients, but it was sales that ultimately counted. A dealer in stocks and bonds who was also a macroeconomic analyst told us that she felt that she had to work at the trading table when the exchange was open. The short-term gains of trading overruled the long-term investment in macroeconomic analysis:

'The problem is that working for the customers brings income. When trading you can see the money coming in by the hour, but analyzing you don't earn money... In trading everybody is concerned about earning money. After all, that's the mark of a good trader.'

Measuring sales on a daily basis, personal qualities of the dealers and their ability to create good relations with the customers was more important than professional competence, according to the analysis of the manager (Rasmussen 2005).

The finance institution tried out their recruits in different trading jobs. These were not jobs that were suited for everyone. Traders used their 'gut feeling' to 'feel' where the market was heading. According to the manager, the ones who thought too much or had to analyze the situation did not manage the pressure of trading. Many competent and well-qualified recruits therefore had, in the words of their manager, "to be coached out" or transferred to other positions in finance or banking. Even for those who did well as traders, the job was not seen as a long-term occupation. Their most experienced trader had worked as such for 10 years, and that was exceptional. It was expected that the traders would either move 'backstage' as analysts, to corporate finance, to the mother bank, or to one of the large customers. Some of the traders ended up as taxi drivers, according to management. The stress of the job made them unsuited for a normal office job (Rasmussen 2005). 
The employees in these organizations could experience a hard time in their trial period when they had to show that they were worthy and able to manage their tasks and be accepted as competent and profitable workers. Many lost in the competition and were counseled out, but the ones who managed to survive and gain a position that gave them authority and autonomy at work could look forward to a professional career in the organization (Håpnes \& Rasmussen 2011a).

\section{Franchise in research}

In the departments of the international research institution, we found a traditional project organization where the research scientists, and especially the seniors, were responsible for the development and contracting of new projects. Their market relations were based on long-standing professional relationships, often forged when they were students at the technical university. Their networks were therefore often personal and the relations were based on trust in their and the research institutions' professional standing and past successes. However, changes in the relation between the public sector and private businesses in Norway inspired by new public management (NPM) led to radical changes in the market situation. Under the new NPM regime, public units could no longer contract research projects directly through negotiations with research institutions, but had to invite for tenders. The IT research department had for many years collaborated successfully with several state departments and public agencies developing cutting-edge systems. They had been able to pick and choose among large innovative research projects. The change posed a serious challenge to them. Where they used to cooperate with their user organizations and propose new projects based on their expert knowledge, they were now expected to bid for projects defined and specified by agents who were not in the front of technological developments. Who won the projects was often more a question of price than of scientific quality. Changes in the relations between the R\&D institutions and the public sector thus threatened the long-standing market relations based on trust and professional expertise. In the IT department it meant that young researchers without market relations were pressured to bid for projects in areas that were far from their professional expertise. During our data collection, the organization was forced to downsize.

The research institution had already established principles for calculating the necessary earnings for individuals and departments. They were based on the cost of running of the department, central management and administration, plus reserves. Systems for registering and billing hours for the projects generated automatically account for the earnings of the individual researchers and departments. These were administrative systems that kept account of the economic situations of the projects and the organization. The changes in the market situation and the new NPM-inspired regime, however, changed the function of the traditional accounting systems into a performance management system. In the new and insecure situation, central management increased their control over the weekly and monthly earnings. At the same time, the influence of local and central management over the market decreased. Under the threat of a market they were unable to control, managers and researchers alike felt they were in the same boat. When 'the market' was not willing to pay more for a project, this was not easy to challenge. 
Everybody knew that their employment was dependent upon their being successful in the market, and the higher up in the professional hierarchy, the greater the pressure to secure money for others as well as themselves. The accounting systems that produced the daily, weekly, or monthly results of each employee made success or failure visible for everyone. To be without paid projects, even for a short period, was a strain even for well-established experts, and failing in the market was always a threat to their position in the organization.

Whereas departments used to be able to offer training in research in their fields through working on projects, in the current market situation, they were no longer able to accommodate gradual training of their young researchers. They therefore collaborated with university faculty to organize $\mathrm{PhD}$ positions at the university to give the young researchers the opportunity to specialize, publish, and develop their professional networks so that they could come back as experts. This was also offered to the young scientists when the IT department had to downsize, as an alternative to leave for employment elsewhere.

The visible daily, weekly, or monthly accounting of each individual's contribution to the organization's economic results, combined with their insecure market situation, had as a consequence that the permanent employment relations in the R\&D departments changed their meaning. It no longer meant what it used to mean: that their employing organization felt responsible for the research scientists and their fields of expertise in a long-term perspective. Instead, they were increasingly made individually responsible for their professional development, contracting the projects, planning the work, and producing the results at the right quality, under the company's logo. "A sort of franchise relation" as one of the informants called it. The research institution showed more concern about the economic results of the departments and less about the professional results of their projects.

\section{Life-long employment}

Employment in the industrial corporation was characterized by long-term commitment from both employer and employees and a promise of an internal career in the organization. The precondition for this relation was that the company had a measure of control over the market situation making long-term planning possible. This was the only organization in our sample that kept to the 'old deal' and hired workers in a long-term perspective, training them in the firm and offering a career for all types of workers. The company was large with international subsidiaries and a wide range of activities and types of workers. They wanted to be a family-friendly employer and had a policy of hiring women. They were therefore very attractive in the labor market and the employees were allowed reduced working hours to better fulfill family obligations without forsaking professional opportunities or management careers (Håpnes \& Rasmussen 2011b).

The company had an active personnel or human resource management function where the demands from the project managers in the matrix organization were counterbalanced by department managers who were responsible for the professional development, career, and personal welfare of their workers. Project managers were primarily concerned with the needs of their projects and not with the pressure of work for the employees or their need for learning and professional development and careers. The 
department manager's responsibility for human resources was therefore important in protecting the workers from participation in too many projects. In this employment relation, the company was both 'father' and 'mother' to the workers, protecting them and guiding them toward a successful professional career in the company. The workers were in turn grateful for the opportunities and care shown by the company and were willing to work hard and take responsibility for the company's needs (see also Håpnes \& Rasmussen 2011b).

The industrial company was, however, increasingly exposed to market forces. They had experienced structural changes in the market that made employees redundant. As a company that felt responsible for their employees, they had managed this by training the people who were redundant for other positions. To prevent further redundancy, the company had a policy of keeping the permanent employees below their actual need for manpower by contracting out projects to long-term partners and hiring workers temporarily on 3-year projects. For workers, these temporary assignments in the good company was a welcome opportunity to make themselves visible as interesting workers for the company with the hope of securing a permanent position. They felt that they, like the trainees described earlier, had to work extra hard and long hours to show themselves as attractive and indispensable for the organization in order to gain a position in the company (Håpnes \& Rasmussen 2011b).

\section{A new deal?}

We asked in this article how we could understand changes in employment relations and whether they were caused by powerful portfolio workers or whether work still matters and increased turnover was the result of changing employment practices. We found in our studies that employment relations were changing, not because of egoistic careerseeking employees, but because the employees were offered more insecure employment. The increased turnover in knowledge organizations in our study was due to new deals at work, i.e., changes in the working conditions and social contracts that were offered by their employers. Our findings therefore support the argument that increased mobility and turnover is a consequence of more insecure and unbalanced employment relations (Rousseau 1995; Sennett 1998).

Could we see a conscious strategy as the new deal that Cappelli (1999) describes? We found a conscious strategy of recruitment and selection in the financial institution and the public relation agency. Both were actively recruiting at leading universities and trained and followed up their recruits, including trying them out and counseling out the ones they did not want. This is a relatively new practice in Norway, but one that we also find in Brown and Hesketh's (2004) study of the (mis)management of talent in the UK. In the industrial company with life-long permanent employment, we found a human resource strategy to protect workers from overwork and secure their professional development and careers. Part of that strategy was using temporary positions as a buffer. Temporary positions in the company were attractive because they might result in a permanent position like the case had been for other temporary workers. In general, the increased insecurity that we found was less a result of a calculated policy and more of the free play of market forces in the daily work situation of the knowledge workers. We saw, however, increased central control of economic results in the face of market 
problems (Clegg, Courpasson \& Phillips 2006; Courpasson 2000). This supports Doogan's argument that the most important environmental factor when it comes to work insecurity is the qualitative greater exposure of the workforce to market forces and a growing awareness of its instability (Doogan 2001).

\section{Work matters}

The ways in which employment relations were changing differed. They were shaped by the history, institutional context, and markets of the organizations. The long-term or short-term perspective of the firm was most decisive. The dot.coms had a short-term perspective dominated by their goal to sell the business or go public and realize the value of their efforts in the stock market. The intense, but short employment relationship in the dot.com organizations was a result of the seduction of young and eager workers through exciting tasks and opportunities in a new field of work. When they realized that they were not taken seriously as knowledge workers, not listened to when they suggested improvements (Hirschman 1970), and treated like cheap labor power that could be put to work days and nights, they felt deceived and left.

The young graduates in finance and public relations were also attracted by interesting work, attractive colleagues, and organizations with opportunities. After they were carefully selected as recruits, they had to demonstrate their value for the firm, often in direct competition with each other to win a permanent position. The demands of shareholders for profit from their investment influenced the public relations agency. Their focus on economic results and billable hours undermined the internal training in the trial period and led to a market-based short-term employment relation (Håpnes \& Rasmussen 2011a). In the financial institution, personal and relational qualities turned out to be more important than professional competence when short-term sales was the measure of success (Rasmussen 2005).

The research institution had traditionally invested in their employees in a longterm perspective and been a responsible employer, but changes in the market due to the introduction of NPM principles in the public sector made this difficult. They were no longer able to train the scientists in the departments like they had previously done, but had to leave the responsibility for the training to the individual researchers and the university. The marketization of the employment relation (Kunda \& Ailon-Souday 2004) also made the research scientists individually responsible for acquiring projects and producing results. If their markets failed or they did not succeed in establishing themselves in new markets, there was no longer work for them. The research institution showed less concern about securing their knowledge capital than the economic results of their projects. The traditional management of scientists and engineers in research and development that Causer and Jones (1996) describes as personalized, motivational, and flexible changed toward indirect control through monitoring of performance and the introduction of market forces directly. When the market forces became more pressing than they had been previously, employment in the research institution was no longer such a good deal. The "franchise" relation for the workers made it a 'do-it-yourself job' where the role of management was being reduced to control of the economic results at the collective and individual levels (Clegg et al. 2006; Courpasson 2000). 
The industrial company with its life-long marriage had a very long perspective on their business and invested in the knowledge of their workers. The organization was attractive because it offered interesting jobs and promises of professional development and a career in the company. The workers who had secured a permanent position felt a strong obligation and were willing to take responsibility for the organization that offered them such opportunities. The workers on temporary contracts, however, were disciplined to work extra hard and not protest, with a hope of acquiring a permanent position in the company.

The turnover and mobility that we found in our studies was therefore not a result of profit-seeking portfolio workers, but rather of workers who strongly identified with their work, but felt forced to leave. When they left, it was either because it was no longer possible to do a good job and they were disillusioned with the company and gave up trying to affect changes as in the dot.com sector, or because they were not among those chosen for a permanent position and were counseled out in the trial period, or because they were no longer able to sell their expertise in the market like we saw in the departments of the research institution. Their exits were therefore the result of the employment practices of their employers and their market situation.

When the relations between knowledge workers and their employers where they worked were changing and we could see signs of what Peter Cappelli (1999) has called a new deal at work, this was not because the formal employment contract had changed from permanent to temporary (with the exception of the temporary employees in the R\&D department of the industrial organization), but because the nature of permanent employment for knowledge workers in ordinary permanent jobs had changed. The changes were in the practices of employment relations that were developing with devolved responsibilities for the results and the market performance to the individual knowledge workers. It was therefore the new social contracts as they were practiced by the employers and experienced by the employees that changed the employment relations in the different contexts of knowledge work that we studied.

The discourse of egoistic, disloyal portfolio workers (or generation $\mathrm{X}$ or $\mathrm{Y}$ ) is, despite the lack of evidence, often used as an explanation for changes in employment relations; that relations are changing because firms have to adapt to a new type of workers. In this sense the idea of portfolio workers is strong and has effects upon employment relations even if empirical studies of knowledge workers and their employers do not confirm this idea. Having followed the firms since our data collection (except for the dot.coms that were bought by multinationals or went bankrupt), we have observed that the development we found toward more insecure employment relations has continued in spite of an increased labor shortage of professional workers in the labor market. Marketization of the knowledge work organizations and reduced loyalty from the employers toward the knowledge workers may therefore encourage strategic market behavior by employees. When employers are only interested in their short-term economic results and no longer loyal to the knowledge workers or investing in their 'knowledge capital,' the workers with the highest earning capabilities may be the first to leave for another employer who offers them a better deal, like the workers in the dot.com firms. Thereby marketization of the knowledge organizations and a perspective on short-term economic gains of the firms may well produce turnover and mobility when knowledge workers are in demand in the labor market. In this way the introduction of market forces in the management of knowledge workers could produce the problem of disloyal portfolio workers, making the idea a self-fulfilling prophecy. 


\section{References}

Alvesson, M. (1998) 'Gender relations and identity at work: A case study of masculinities and femininities in an advertising agency', Human Relations, 51(8): 969-1005.

Alvesson, M. (2000) 'Social identity and the problem of loyalty in knowledge-intensive companies', Journal of Management Studies, 37(8) (December): 1101-1123.

Alvesson, M. (2004) Kunnskapsarbete och kunnskapsföretag. Kristianstad: Liber.

Baldry, C., Bain, P., Taylor, P., Hyman, J., Scholarios, D., Marks, A., Watson, A., Gilbert, K., Gall, G. and Bunzel, D. (2007) The Meaning of Work in the New Economy. Basingstoke: Palgrave Macmillan.

Barley, S. and Kunda, G. (2001) 'Bringing work back in', Organization Science, 12(1): 76-95.

Barron, J. N., Hannan, M. T. and Burton, D. (2001) 'Labor Pains: Change in organizational models and employee turnover in young, high-tech firms', American Journal of Sociology, 106(4): 960-1012.

Beck, U. (2000) The Brave New World of Work. Cambridge: Polity.

Beck, U. (2002) Individualization: Institutionalized Individualism and its Social and Political Consequences. London: Sage.

Brown, P. and Hesketh, A. (2004) The Mismanagement of Talent. Employability and Jobs in the Knowledge Economy. Oxford: Oxford University Press.

Cappelli, P. (1999) The New Deal at Work. Managing the Market-Driven Workforce. Boston: Harvard University Press.

Castells, M. (1996) The Rise of the Network Society. Oxford: Blackwell.

Causer, G. and Jones, C. (1996) 'Management and the control of technical labour', Work, Employment \& Society, 10(1): 105-123.

Clegg, S., Courpasson, D. and Phillips, N. (2006) Power and Organizations. London: Sage.

Courpasson, D. (2000) 'Managerial strategies of domination. Power in soft bureaucracies', Organization Studies, 21(1): 141-161.

Darr, A. and Warhurst, C. (2008) 'Assumptions, assertions and the need for evidence: Debugging debates about knowledge workers', Current Sociology, 56: 25-45.

Deetz, S. (1995) Transforming Communication, Transforming Business: Building Responsive and Responsible Workplaces. Creskill, NJ: Hampton Press.

Doherty, M. (2009) 'When the working day is through: the end of work as identity?' Work, Employment \& Society, 23(1): 84-101.

Donnelly, R. (2009) 'The knowledge economy and the restructuring of employment: the case of consultants', Work, Employment \& Society, 23(2): 323-341.

Doogan, K. (2001) 'Insecurity and long-term employment', Work, Employment \& Society, 15(3): 419-442.

Doogan, K. (2005) 'Long-term employment and the restructuring of the labour market in Europe', Time \& Society, 14(1): 65-87.

Drucker, P. F. (1993) Post-Capitalist Society. Oxford: Butterworth-Heinemann.

Elliot, L. and Atkinson, D. (1998) The Age of Insecurity. London: Verso.

Epstein, C. F., Seron, C., Oglensky, B. and Sauté, R. (1999) The Part-Time Paradox. New York: Routledge.

Felstead, A., Burchill, B. and Green, F. (1998) 'Insecurity at work', New Economy, 5(3): 180-184.

Gouldner, A. W. (1960) 'The norms of reciprocity: A preliminary statement', American Sociological Review, 25, April, 161-178.

Halrynjo, S. (2007) 'Alltid beredt? Arbeids- og familiedilemmaer i møte med formelle og uformelle spilleregler i et stort konsern', in Kvande, E. and Rasmussen, B. (eds.) Arbeidslivets klemmer. Bergen: Fagbokforlaget, 81-107. 
Handy, C. (1989) The Age of Unreason. London: Business Books.

Håpnes, T. and Rasmussen, B. (2008) 'Postbyråkratiske organisasjoner - et inkluderende arbeidsliv?' Tidsskrift for Velferdsforskning 11(1): 34-49.

Håpnes, T. and Rasmussen, B. (2011a) 'Presteskap, byråkrati og marked. Forsøk på å konstruere en moderne kunnskapsorganisasjon', Nordiske Organisasjonsstudier, 13(2): $35-56$.

Håpnes, T. and Rasmussen, B. (2011b) 'Policies and practices of family friendliness. Time and employment relations in knowledge work', Nordic Journal of Working Life Studies, $1(2): 39-57$.

Hirschman, A. (1970) Exit, Voice and Loyalty. Cambridge, MA: Harvard University Press.

Kanter, R. M. (1989) When Giants Learn to Dance. Mastering the Challenges of Strategy, Management, and Careers in the 1990s. New York: Simon \& Schuster.

Kitterød, R. H. and Rønsen, M. (2010) 'Yrkesarbeid blant par. Når jobber hun minst like mye som han?' Samfunnsspeilet, 24(1): 43-54.

Kunda, G. and Ailon-Souday, G. (2004) 'Managers, markets, and ideologies. Design and devotion revisited', in Ackroyd, S., Batt, R., Thompson, P. and Tolbert, P. S. (eds.) The Oxford Handbook of Work and Organization. Oxford: Oxford University Press, 200-220.

Mintzberg, H. (1979) The Structuring of Organizations. Englewood Cliffs, NJ: Prentice Hall.

Newell, S., Robertson, M., Scarborough, H. and Swan, J. (2002) Managing Knowledge Work. Basingstoke: Palgrave.

Olsen, K. M. and Kalleberg, A. (2004) 'Non-standard work in two different employment regimes: Norway and the United States', Work, Employment \& Society, 18(2): 321-349.

Rasmussen, B. (2005) 'Gut feeling, back-slapping - Gendered embodiment on the exchange', in Morgan, D., Brandth, B. and Kvande, E. (eds.) Gender, Bodies and Work. Ashgate: Aldershot, 61-75.

Rasmussen, B. (2008) 'Kunnskapsorganisasjoner - postbyråkrati eller markedsstyrt?’ Nordiske Organisasjonsstudier 10(3): 7-29.

Rasmussen, B. and Johansen, B. (2002) 'Å sage over den greina man sitter på’, Sosiologisk Tidsskrift, 10(4): 332-354.

Rasmussen, B. and Johansen, B. (2005) 'Trick or treat? Autonomy as control in knowledge work', in Barrett, R. (ed.) Management, Labour Process and Software Development. London: Routledge, 100-123.

Robertson, M. and Swan, J. (2004) 'Going public: The emergence and effects of soft bureaucracy within a knowledge intensive firm', Organization, 11(1): 123-148.

Rousseau, D. (1995): Psychological Contracts in Organizations. Thousand Oaks: Sage

Scarborough, H. (1999) 'Knowledge as work: Conflicts in the management of knowledge workers', Technology Analysis and Strategic Management, 11(1): 5-16.

Schein, E. (1985) Organizational Culture and Leadership. San Francisco, CA: Jossey Bass.

Sennett, R. (1998) The Corrosion of Character. New York: Norton.

Sennett, R. (2004) Respect: The Formation of Character in an Age of Inequality. London: Penguin.

Standing, G. (2009) Work after Globalization: Building Occupational Citizenship. Cheltenham: Edward Elgar.

Voss-Dahm, D. (2005) 'Coming and going at will? Working time organization in German IT companies', in Barrett, R. (ed.) Management, Labour Process and Software Development. Reality Bytes. London: Routledge, 123-146.

Warhurst, C. and Thompson, P. (2006) 'Mapping knowledge in work: proxies or practices?' Work, Employment \& Society, 20(4): 787-800. 


\section{End note}

${ }^{1}$ The exception is when a permanent employee is temporarily absent (due to parental leave or other types of leave (sick leave, educational leave, etc.)). Because of extensive leave provisions in the Norwegian labor law, there are very many Norwegian employees on short-term contracts (Olsen \& Kalleberg 2004).

${ }^{2}$ The project ("Grenseløse jobber og grådige organisasjoner") was financed by the Norwegian University of Science \& Technology (NTNU) and the data collected in 1999 and 2000.

${ }^{3}$ The project ("Fra faste forhold til løse forbindelser") was financed by the Work-life programme of the Norwegian Council for Research (156100) and the data collected in 2003 and 2004. 